\title{
If One Can't Lose Such a Right in These Circumstances, One Never Had It in the First Place
}

\author{
Michael Otsuka ${ }^{1}$ (D)
}

Accepted: 12 June 2021 / Published online: 29 June 2021

(c) The Author(s) 2021

\begin{abstract}
In this article, I press a line of objection to Jonathan Quong's moral status account of liability to defensive harm. The claim on which I rest my critique is captured by the article's title: if one can't lose such a right in these circumstances, one never had it in the first place.
\end{abstract}

Keywords Quong · Self-defence · War · Liability · Defensive harm · Moral status account $\cdot$ Moral responsibility account $\cdot$ Rights

On what has come to be known as the 'moral responsibility account' of liability to defensive killing, it is one's moral responsibility for being a threat, rather than culpable behaviour, that renders one liable to defensive killing. Moreover, one's lack of moral responsibility for being a threat grounds one's nonliability to defensive killing. Among its many virtues, The Morality of Defensive Force offers a sustained and powerful critique of the moral responsibility account. Jonathan Quong also offers an alternative account of liability to defensive killing, which he calls the 'moral status account'. I have defended the moral responsibility account and am one of the targets of Quong's critique. ${ }^{1}$ In this article, I press a line of objection to his moral status account.

\footnotetext{
1 I offer such a defence in 'Killing the Innocent in Self-Defense', Philosophy and Public Affairs 23 (1994): 74-94, and 'The Moral Responsibility Account of Liability to Defensive Killing', Christian Coons and Michael Weber, eds., The Ethics of Self-Defense (Oxford University Press, 2016), pp. 51-68.
}

\begin{abstract}
I presented an earlier version of this paper at a conference in 2018 at the University of Warwick on a draft of The Morality of Defensive Force. I thank Jonathan Quong and the other participants for their comments on that occasion. On pp. 164-166 of the published version of his book, Quong engages with the line of criticism I press here. See my quotations from p. 165 below and my response which follows.
\end{abstract}

Michael Otsuka

m.h.otsuka@1se.ac.uk

1 Department of Philosophy, London School of Economics, London, UK 
I shall orient my discussion around two cases in which, on the moral responsibility account, it is deemed permissible to kill another in self-defence because she is morally responsible for her behaviour even though she is also blameless. As we shall see in a moment, Quong's moral status account reaches a different verdict regarding permissibility across these two cases.

The first case involves someone who mistakenly but non-culpably tries to kill an innocent person in self-defence:

Mistaken Attacker: The identical twin brother of a notorious serial killer is driving during a stormy night in a remote area when his car breaks down. Unaware that his brother has recently escaped from prison and is known to be hiding in this same area, he knocks on the door of the nearest house, seeking to phone for help. On opening the door, Resident justifiably believes the harmless twin is the killer. Resident has been warned by the authorities that the killer will certainly attack anyone he meets on sight, and so Resident lunges at him with a knife. $(23-24)^{2}$

If mistaken Resident stabs the innocent twin, he would be doing something that appears to be objectively wrong: he would be killing a nonresponsible person who, it seems, is not in fact liable to be killed, and whose killing cannot be justified on any other objective grounds either. But such a killing would be subjectively morally justifiable, since mistaken Resident would be acting on the justified (but false) belief, grounded in a reasonable assessment of the evidence, that he is defending himself against an attack by a culpable serial killer.

Is mistaken Resident liable to be defensively killed, if this is the only way to save the life of the innocent stranded twin? Proponents of the moral responsibility account maintain that he is. They infer liability on grounds that, as I wrote in 1994, a morally 'responsible agent takes a gamble by placing [his] moral immunity on the line when [he] engages in such avoidable risky activity' as the lunging at someone with a knife. ${ }^{3}$ There I was drawing an implicit analogy between the bad moral luck of becoming morally liable to be killed and Ronald Dworkin's notion, within the realm of distributive justice, of bad option luck. Someone voluntarily chooses to gamble with his moral worth, so to speak, by knowingly engaging in risky activity that might imperil the innocent. Mistaken Resident who tries to stab someone who turns out to be innocent is morally unlucky in much the same way as someone who gambles on the stock market and loses is financially unlucky. The upshots of such gambles are not unfair because they are a matter of bad option luck rather than bad brute luck. ${ }^{4}$

\footnotetext{
2 All such parenthetical references are to The Morality of Defensive Force.

3 'Killing the Innocent in Self-Defense', p. 91.

4 Option luck, as Dworkin defined it, is 'a matter of ... whether someone gains or loses through accepting an isolated risk he or she should have anticipated and might have declined'. Brute luck, by contrast, is 'a matter of how risks fall out that are not in that sense ... gambles'. See Dworkin, 'What is Equality? Part II: Equality of Resources', Philosophy and Public Affairs 10 (1981): 283-345 at p. 293.
} 
Now let us contrast the case of mistaken Resident with the following case, which involves someone who accidentally, and non-culpably, imperils the life of another:

Conscientious Driver: Driver, who always keeps [her] car well maintained and always drives carefully and alertly, decides to drive to the movies. On the way a freak accident occurs that causes [her] car to veer out of control in the direction of a pedestrian. The out-of-control car will now kill the pedestrian unless the pedestrian destroys the car with a grenade, thereby killing Driver. $(26-27)^{5}$

Jeff McMahan, who is the originator of this case, offers the following commentary on it, with which I am in agreement:

Although her act is of a type that is generally objectively permissible, and although she has taken due care to avoid harming anyone, she has had bad luck: the risk she knew her act carried has now, improbably and through no fault of her own, been realized. Because she knew of the small risk to others that her driving would impose, and because she nonetheless voluntarily chose to drive when there was no moral reason for her to do so[,] ... she is morally liable to defensive action to prevent her from killing an innocent bystander. ${ }^{6}$

Quong concurs with McMahan and me that mistaken Resident has, by lunging at an innocent with a knife, rendered himself liable to be defensively killed. Yet he rejects our claim that conscientious Driver has also rendered herself liable. He rejects our moral responsibility account of liability in favour of his moral status account, which is attentive to an interesting feature that is alleged to differentiate mistaken Resident from conscientious Driver. According to Quong, in lunging with a knife at the person whom he believes to be threatening his life, mistaken Resident acts as if the person whom he confronts lacks rights that he in fact possesses. Moreover, Quong maintains that to 'treat others as if they lack moral rights against having harm imposed is a grave matter' (39). He says that:

When you act in this way, you treat others as if they are not entitled to the equal concern and respect all persons are normally owed, and so it's appropriate that you bear special liability for your actions when the people you harm do in fact have rights against the harmful acts you perform. (8)

By contrast, conscientious Driver never acts on the assumption that anyone lacks rights that she in fact possesses. The justification of our traffic laws to which she conforms - which appeals to a calculation of the costs and benefits of driving, including the cost of accidental deaths-does not depend on any assumption that people lack rights not to be harmed that they in fact possess. Nor, of course, does

\footnotetext{
${ }^{5}$ Derived from McMahan, Killing in War, p. 165. Both Quong and McMahan also discuss a variant involving an ambulance driver. To differentiate the ambulance driver from the conscientious driver, we might appeal to the relevance of the roles they occupy. See my discussion of the relevance of roles in 'Moral Luck: Optional, not Brute', Philosophical Perspectives 23 (2009): 373-88.

6 Killing in War, p. 166.
} 
she hurtle accidentally out of control towards a pedestrian on the assumption that this pedestrian lacks rights not to be harmed. Of such a case, Quong writes:

$[\mathrm{U}]$ nlike the moral responsibility view, the moral status account does not implausibly declare that [conscientious] Driver [is] liable to defensive harm. ... [T]he evidence-relative permissibility of getting behind the wheel of a vehicle and imposing a tiny risk of harm on others does not depend on treating those others as if they lack any rights against harm. (39)

Conscientious Driver is nonliable to defensive harm for the following reason:

[W] hen you do not treat others as if they lack rights against harm-when the justification for your act accords the appropriate weight to the moral claims each person has-then it would be unreasonable to hold you liable for the harms that result from your act. (20)

More generally, Quong writes:

[T] he moral status conception declares that what matters is whether a person, judged from the evidence-relative standpoint, acts as if others lack rights against harm. When, and only when, our actions have this particular featuretreating others with something less than the concern and respect they are due-we make ourselves liable to defensive harm. (41)

Quong has identified a deep and interesting moral difference between cases in which one treats others as if they lack rights that they in fact possess and cases in which one does not treat others in this way. Nevertheless, I shall argue that Quong's appeal to this distinction ultimately fails to support his position that mistaken Resident is liable to defensive killing, whereas conscientious Driver is not. This is because the very considerations regarding the reasonableness of our demands that Quong advances in support of the nonliability of conscientious Driver will carry over to immunise mistaken Resident from such liability as well. These considerations will establish that we should never have posited that the twin had a right in the first place not to be subject to Resident's defensive attack.

I should note that I am offering an internal critique of Quong's position. I am, however, somewhat sceptical of Quong's claim that one establishes what claim rights people have on the basis of the considerations he offers regarding the correlative duties it is reasonable to demand of others. Moreover, such an approach to ascertaining what rights we have would, I believe, be difficult to square with the moral responsibility account that I have defended. In the remainder of this article, I shall mainly bracket these general doubts and assume, for the sake of argument, the perspective of someone who accepts Quong's approach to establishing rights by means of a particular account of what it is reasonable to demand of others.

Without further ado, here is my critique.

In explaining why conscientious Driver is not liable to be killed, Quong writes:

[W] e only have moral rights that others refrain from performing harmful (or potential harmful) acts when we can reasonably demand that they refrain from performing the act. It's not reasonable to demand that others refrain from care- 
ful and conscientious behaviour when the behaviour poses only an extremely low risk of harm .... (5)

My challenge to Quong is this: someone who believes this about conscientious Driver must, on pain of inconsistency, also maintain that it is unreasonable to demand that mistaken Resident refrain from engaging in defensive force when faced with his predicament.

According to Quong, mistaken 'Resident acts on the basis of justified beliefs', and therefore "his act of "self-defense" is permissible in the evidence-relative sense. He thus cannot be culpable- he has a full epistemic excuse' (24). How, in the light of this, can it be reasonable to demand that mistaken Resident refrain from doing that which a reasonable assessment of the evidence implies to be necessary to save his own life from an attack by a culpable aggressor who has forfeited his immunity from defensive harm?

On behalf of his claim that mistaken Resident renders himself liable to be killed, Quong maintains that 'Surely Resident lacks the standing to complain if the twin must break Resident's arms to prevent himself from being killed' (24). While this may be true, it does not serve to differentiate mistaken Resident from conscientious Driver. This is because conscientious Driver would also lack standing to complain if Pedestrian must break Driver's arm to save his own life. In both cases, we would be able to appeal to a lesser evil justification for imposition of the lesser harm on one of two non-culpable parties.

In differentiating conscientious Driver from mistaken Resident, Quong appeals to a more general distinction, which is captured by the following pair of questions:

1. Under what conditions does a person have a claim not to be harmed by a particular type of act performed by another person?

2. Has some particular person, A, waived, transferred, or forfeited this claim not to be harmed by another person, B? (162)

Quong maintains that 'The answer to the latter question depends on what A has actually done, and not on B's evidence about what A has done' (162). This is because 'there are powerful reasons why transfer, waiver, and forfeiture should depend on what the right-holder actually does rather than anyone's evidence about what she's done. Most importantly, this grants the right-holder a more effective degree of control over the right, something that is typically of central importance' (165). Quong maintains, however, that:

the same argument doesn't apply to the question of whether someone has a right in the first place. When we're deciding whether persons in general have a right that others refrain from $\Phi$-ing, it makes sense to focus on what we can reasonably demand of others. For example, can I reasonably demand that no one speak at a volume louder than a whisper on a busy city street? (165)

These remarks apply to mistaken Resident as follows: Having established that the twin who knocks on Resident's door has a right not to be subject to lethal defensive harm, it follows that the twin is not liable to suffer such harm unless he has 
waived, transferred, or forfeited his claim not to be harmed. Moreover, he waives, transfers, or forfeits his right only by behaving in a particular fashion, which is a matter of the facts rather than the evidence available to Resident.

I would now like to press the following challenge to Quong's attempt to differentiate mistaken Resident from conscientious Driver. Recall that I pressed the point earlier that it would be unreasonable to expect Resident to refrain from defending himself in the predicament in which he finds himself. Now I can fully grant Quong's claim that such unreasonableness does not bear on the question of whether the twin has waived, transferred, or forfeited any right he possesses not to be subject to lethal defensive harm. Such unreasonableness does, however, bear on the question of whether we should have posited that the twin ever had a right in the first place against being subject to lethal defensive harm in the circumstances in which he found himself. Nothing Quong has said blocks the following challenge: Given the unreasonable burden on people in the predicament of mistaken Resident that such a right would impose, we should never have posited a right in the first place against being subject to defensive harm in the circumstances in which the twin found himself. It would in fact be unreasonable to posit such a right in the first place precisely because, on Quong's account, the rightsbearer exercises extensive control over whether he loses his right. He cannot lose such a right simply by inadvertently and innocently manifesting overwhelming evidence to any reasonable observer that he is a dangerous serial killer who is about to attack.

Quong opens himself up to my challenge when he writes the following:

To establish a person's liability to defensive force, we must ask whether that person threatens the moral rights of others by $\Phi$-ing. And the answer to that question cannot be determined by asking whether it would be wrong for the person to $\Phi$ if she knew all the facts. Rather, it must be determined by asking, among other things, what it would be reasonable for others to demand of her given the importance of the affected activities, the costs involved, the options available, and the relative harms that others might suffer. (173, my emphasis)

It would, however, be unreasonable of others to demand that people such as Resident refrain from using lethal force to defend themselves against what any reasonable person would be justified in believing on the evidence to be a culpable aggressor who will murder them if they do not strike first. Given what Quong says in the passage I've just quoted, it follows from such unreasonableness that Resident does not threaten any moral right of the twin in lethally defending himself against him.

I now quote a passage from Quong's book that offers further support of my claim that Resident contravenes no right of others because it would be unreasonable to demand that people in Resident's predicament refrain from exercising defensive force. Quong writes that:

many everyday acts impose very small risks of harm on others, yet these risks are sufficiently low that others cannot reasonably demand that we refrain from performing them, and thus we contravene no person's moral rights in performing these acts. (169) 
Note that innocent people run a very small ex ante risk of being harmed by someone who conscientiously exercises defensive force only in circumstances in which the evidence justifies such force. It would appear to follow from the passage I've just quoted that one cannot reasonably demand that people such as mistaken Resident refrain from performing such defensive acts. The quoted passage therefore appears to commit Quong to the conclusion that Resident does not contravene twin's moral rights in attacking him.

A further problem with Quong's account arises: Why, one might ask, can't the behaviour that, as a matter of fact, results in twin's losing his right not to be subject to defensive force be the behaviour of knocking on mistaken Resident's door while looking just like a dangerous escaped serial killer who will attack unless attacked first? Presumably, Quong's answer would be that, if one could lose one's right in this manner, then one would not have an effective enough degree of control over the right. But we don't ultimately care about the effective degree of control over the rights we have. Rather, we ultimately care about having an effective degree of control over our lives. Such control is reduced not merely by having less control over the rights we possess against being subject to defensive force. It is also reduced by having fewer, rather than more, rights in the first place against being subject to defensive force. For this reason, I do not think Quong can sustain his contrasting approach to answering his two general questions, the first of which is what rights do we have and the second of which is how can we lose those rights.

Open Access This article is licensed under a Creative Commons Attribution 4.0 International License, which permits use, sharing, adaptation, distribution and reproduction in any medium or format, as long as you give appropriate credit to the original author(s) and the source, provide a link to the Creative Commons licence, and indicate if changes were made. The images or other third party material in this article are included in the article's Creative Commons licence, unless indicated otherwise in a credit line to the material. If material is not included in the article's Creative Commons licence and your intended use is not permitted by statutory regulation or exceeds the permitted use, you will need to obtain permission directly from the copyright holder. To view a copy of this licence, visit http://creativecommons.org/ licenses/by/4.0/.

Publisher's Note Springer Nature remains neutral with regard to jurisdictional claims in published maps and institutional affiliations. 